\title{
The 'Modern' View of Macroeconomics: Some Critical Reflections
}

\author{
Alfonso Palacio-Vera \\ Universidad Complutense de Madrid (Spain)
}

\begin{abstract}
Romer has proposed an alternative macroeconomic framework, i.e., the IS-MP-IA model. Its proponents claim that it constitutes a 'modern' view of macroeconomics. We show that the new framework is closely attached to the neoclassical synthesis and, in addition, fails to take account of: (i) the recent empirical evidence on the short-run output-inflation trade-off, (ii) the recent work and evidence on the interdependence of aggregate demand and supply, (iii) the limits of monetary policy and (iv) the consequences for demand-management policy of (i), (ii) and (iii). Once all these aspects are incorporated, we have that short-run stabilization policy is non-neutral in the long run, loanable funds theory becomes irrelevant and aggregate demand becomes the crucial exogenous variable in the short run and, perhaps, also in the long run.
\end{abstract}

Key words: neutrality of money, NAIRU, natural rate of interest, aggregate demand.

JEL Classification: A22, E10, E50, E60

\section{1.- Introduction}

Recent developments in monetary policy have created new and challenging difficulties for the IS-LM-AS model. By far, the most serious one arises from the abandonment of monetary targets by central banks and their subsequent adoption of inflation targeting frameworks where the short-term interest rate is the main instrument of monetary policy (Bernanke and Mishkin, 1997; Bernanke et al., 1999). Given that in the IS-LM-AS model the central bank is assumed to target money supply - with the nominal interest rate being determined in the money market - this policy development has turned the former into an obsolete apparatus. In an attempt to remedy this state of affairs, Romer $(1999,2000)$ and Taylor (2000) have proposed an alternative framework - the IS-MP-IA model - that is to replace the former. An advantage of the new model is 
that, along with recent policy developments, it assumes that central banks target the real interest rate through an interest rate reaction function. Its proponents argue that this change in its specification makes the new framework vastly more relevant for macroeconomic analysis. They also claim that the new framework fits data well, explains policy realistically and represents de facto a 'modern' view of macroeconomics insofar as, at the practical level, it 'is now pervasive in policy-research projects at universities and central banks around the world' (Taylor, 2000, p. 90).

The purpose of this paper is to identify and discuss several controversial issues faced by this new framework. In so doing, three main claims are made. First, it is argued that the assumption that inflation rises (falls) when the output gap is positive (negative) is not a good description of the behaviour of inflation in market economies. An alternative assumption on inflation dynamics that fits empirical evidence better than the assumption made by advocates of the 'modern' view is proposed and some of its consequences analysed. Second, recent work suggests that the axiom of independence of aggregate demand and supply is inaccurate. This axiom constitutes the basis for the long-run monetary policy (and money) neutrality proposition that pervades both the neoclassical synthesis and the 'modern' view. Dropping it leads to policy insights not contemplated in the 'modern' view. In addition, while adherence to the long-run money neutrality proposition makes the new framework remain within loanable funds theory, dropping this proposition makes the latter irrelevant. Third and last, in the 'modern' view it is assumed that the aggregate demand curve is downward sloping in output gapinflation space, where the output gap is defined as usual (Taylor, 2000, p. 91). As a result, it is then assumed - but not demonstrated - that Say's law holds. When put together with the long-run neutrality of monetary policy proposition this means, in turn, that within this theoretical framework, all central banks can do in the long run is to 
determine the rate of inflation and the relative volatility of output and inflation (Taylor, 1994, 1997; Solow and Taylor, 1998). However, we argue below that: (i) the negative slope of the aggregate demand curve crucially depends on the nature of the (nominal) interest rate reaction function of the central bank and is not, therefore, an intrinsic characteristic of the economic system and (ii) the new framework does not possess a convincing self-adjusting mechanism that guarantees that the long-run level of output is supply-side determined. In particular, if the central bank sets the interest rate, money supply is endogenous and the real-balance effect is non-existent (Moore, 1988). Furthermore, when due account is taken of the zero lower bound on the nominal rate of interest, the rate of aggregate demand becomes central to the determination of the rate of output (Keynes, 1936, Ch. 3). In this respect, it is our contention that, although the new framework may well become the 'modern' view of macroeconomics, it does not deserve to be called 'Keynesian', as Romer (2000) does. The structure of the paper is as follows. Section 2 briefly presents the IS-MP-IA model as developed in Romer (1999, 2000) and, to a lesser extent, in Taylor (2000). The IS-MP-IA model provides the basic framework for the 'modern' view of macroeconomics. In section 3 we discuss the analytical problems referred to above. Section 4 presents an alternative framework and section 5 concludes.

\section{2.- The 'modern' view of macroeconomics}

As Romer (2000, p. 154) points out, a key assumption of the new approach is that the central bank acts to make the real interest rate behave in a certain way as a function of macroeconomic variables such as inflation and output. Most central banks target the inter-bank overnight lending rate. For instance, the US Fed targets the federal 
funds rate (Goodfriend, 1991) whereas the ECB targets the euro-overnight-indexaverage (eonia) rate (European Central Bank, 2001, Ch. 4). This phenomenon has been sufficiently documented so that we readily agree that this assumption is a vastly better description of how central banks behave than the assumption that they target money supply ${ }^{1}$. However, what central banks actually set is a nominal rather than a real rate although, what they surely aim at is to target a real interest rate. From an analytical point of view, we think that it is convenient to assume that central banks target the exante real interest rate, i.e., they adjust the nominal rate whenever they perceive that a change in expected inflation or any other macroeconomic variable has made the current ex-ante real interest rate differ from the desired ex-ante real interest rate. From this, it is clear that if the real interest rate rule is to provide monetary policy with a nominal anchor, it has to make the real interest rate an increasing function of either the current rate of inflation or the inflation gap, i.e. the deviation of current from target rate of inflation (Allsopp and Vines, 2000). As Romer (2000, p. 156) points out, 'the simplest real interest rate rule is one that makes the real rate a function only of inflation: $r=r(\pi)$, with the function assumed to be increasing'. This real interest rate rule, which he denominates the MP function (for monetary policy), replaces the LM curve in standard models. In turn, the MP function is presented as a horizontal line in output-real interest rate space, as shown in the upper panel of figure 1 below. Changes in the real interest rate targeted by the central bank are reflected in vertical shifts of the MP line. For instance, if $\pi_{1}>\pi_{0}$, then curve MP1 will be above curve MP0, as shown in figure 1. Finally, the determination of the term structure of interest rates is left aside.

Next, we address the derivation of the aggregate demand curve. As shown in the upper panel of figure 1, a rise in the rate of inflation leads, through the real interest rate rule, to an upward shift of the MP line or, equivalently, to a rise in the real interest rate. 
Since the level of aggregate demand is assumed to be a decreasing function of the real rate of interest, a rise in the latter leads, in turn, to a fall in the rate of output ${ }^{2}$. That is, as the real interest rate rises the economy moves up along the IS curve to the intersection between the IS curve and the MP1 line. Therefore, for a higher rate of inflation $\pi_{1}$, we get a lower short-run equilibrium rate of output. This inverse relation between the inflation rate and output allows us to derive the aggregate demand curve. It is shown in the lower panel of figure 1 below. Therefore, the aggregate demand curve provides the rate of output corresponding to every rate of inflation for a given real interest rate reaction function of the central bank. As we discuss below, both its slope and position depend on the characteristics of the central bank policy reaction function.

The next step is to bring in aggregate supply. Here, Romer follows Taylor's approach which assumes that inflation at any point in time is given and that, in the absence of inflation shocks, inflation rises when output is above its natural rate and vice-versa. As a result, the immediate impact of a variation in aggregate demand falls entirely on output. This assumption implies that the short-run aggregate supply curve (here referred to as the inflation adjustment line or IA) is horizontal in output-inflation space, as shown in figure 2 below. It allows both cost-push inflation and demand-pull inflation to be considered. For instance, when the output gap is zero, the IA line shifts up or down due to the occurrence of unfavourable or favourable inflation shocks respectively. The mechanics of the model are simple: inflation is inherited from the past and determines - through a policy reaction function - the real interest rate that, in turn, determines output. Finally, output - together with inflation shocks - determines the rate of inflation. 


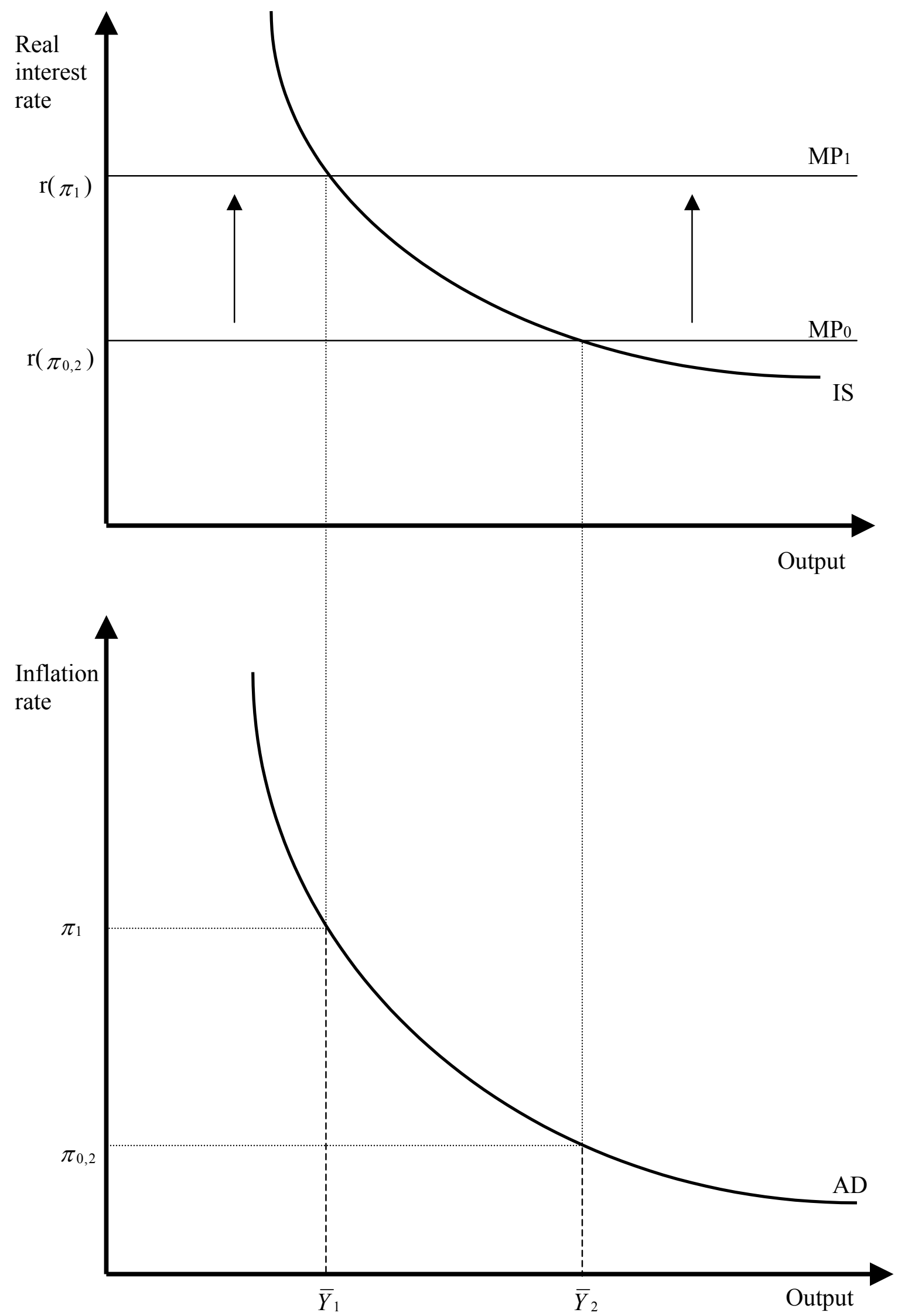

Figure 1: The derivation of the aggregate demand curve 
Finally, we turn to the issue of the self-adjustment mechanism of the economy. When, as shown in figure 2 below, the $\mathrm{AD}_{0}$ curve and the IA0 line intersect at a point where output is below its natural rate $\bar{Y}$, the rate of inflation starts to fall. As this occurs, the IA0 line shifts down. The central bank will then lower the real interest rate and, as a result, output will rise as the economy moves down along the ADo curve. This process is shown graphically in figure 3 below.

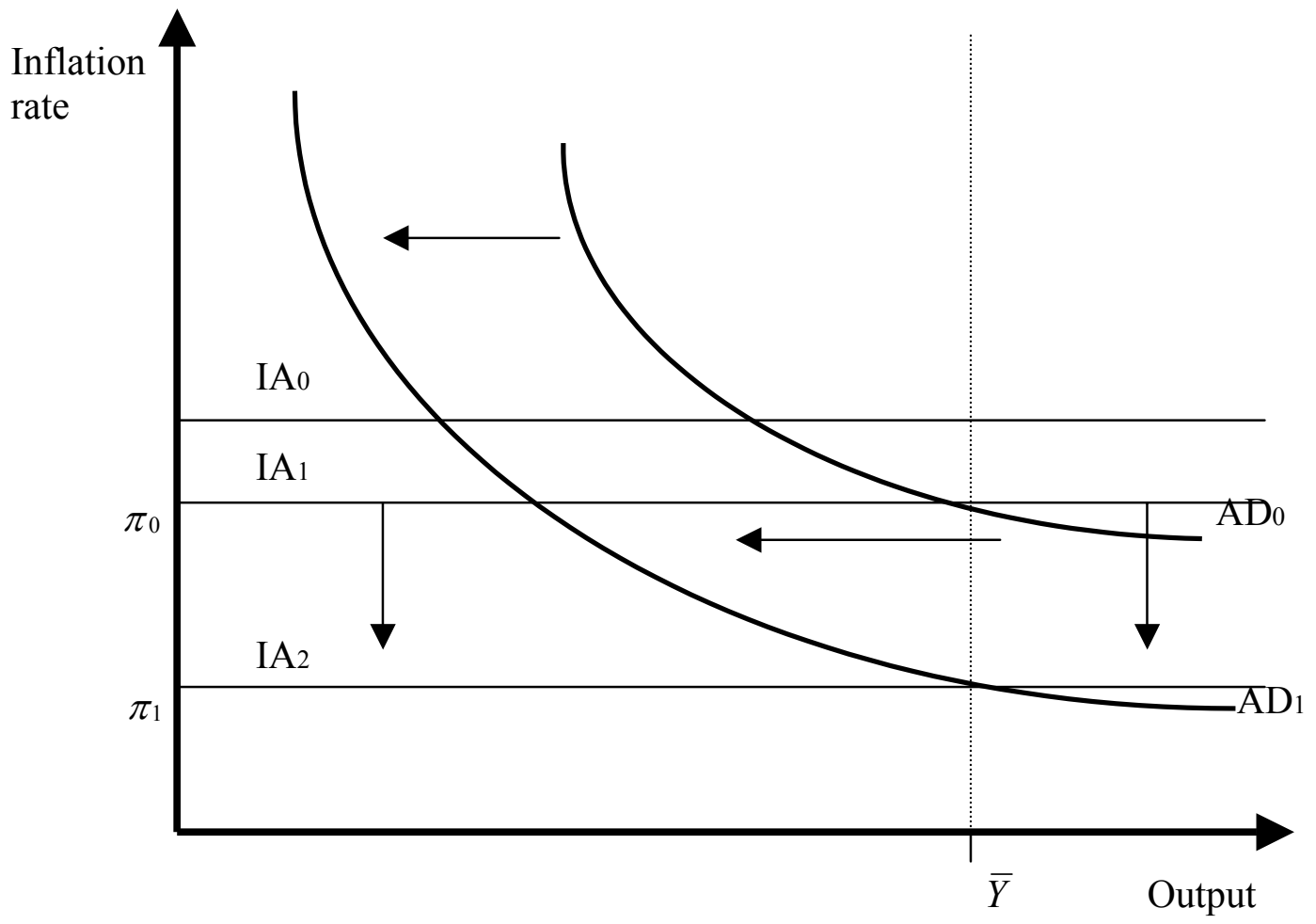

Figure 2: The determination of the inflation rate and the rate of output

As long as current output is below potential, the rate of inflation will keep on falling - albeit at a lower pace as current output approaches $\bar{Y}$ - and the central bank will lower the real interest rate so as to keep output rising. This process stops when $Y=\bar{Y}$. At that point ( $E_{L R}$ in figure 3), the rate of inflation ceases to fall and the central bank presumably sets the real interest rate at exactly that point that generates a rate of 
aggregate demand $\bar{Y}$. At the end of the adjustment process, the economy achieves its long-run equilibrium position at $\bar{Y}$ and, in the absence of inflation shocks that disturb the long-run equilibrium, the rate of inflation will remain constant. As Romer claims, these dynamics are realistic insofar as 'they are consistent with the overwhelming evidence that a disinflation coming from a shift in monetary policy involves a period of below-normal output and high real interest rates' (Romer, 2000, p. 160). Lastly, the real interest rate at $\bar{Y}$ must necessarily be the rate that clears the loanable funds market for a rate of output $Y=\bar{Y}$. Its value ( $r_{L R}$ hereafter) corresponds to the notion of 'natural' real interest rate (Wicksell, 1936) and is determined by the intersection of the MP line and the IS curve at the rate of output $\bar{Y}$. This framework allows us to study the effects of a wide range of demand and supply shocks, analyse different policy strategies and consider the case of an open economy (see Romer, 1999).

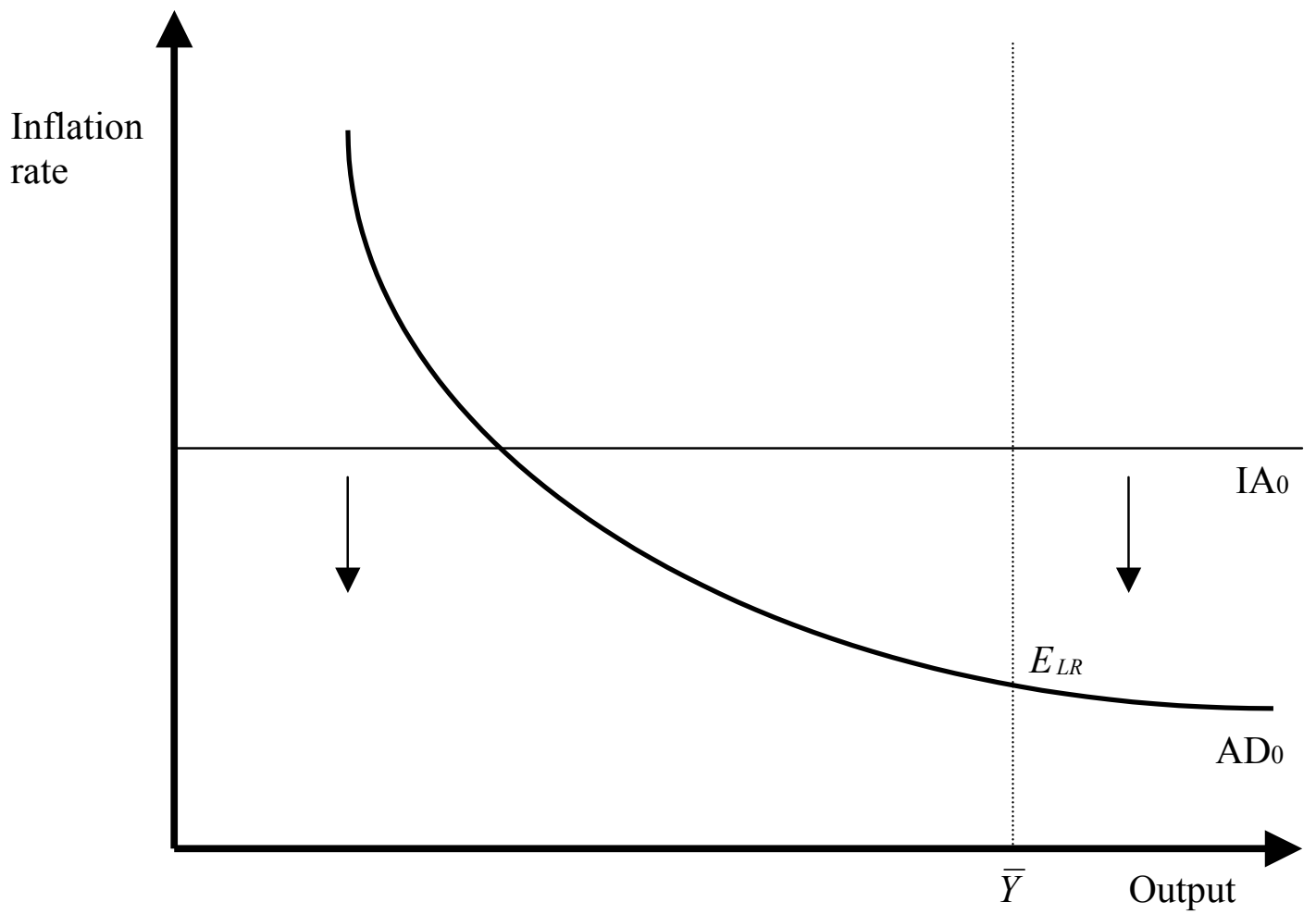

Figure 3: The process of adjustment towards the long-run equilibrium position 
To finish off this section we address the crucial issue of the long-run neutrality of monetary policy. To do so we follow Romer's analysis (Romer, 1999, pp. 43-47). Let us suppose that the central bank implements a tighter monetary policy, e.g. as a result of a reduction in the inflation target. That is, suppose that the central bank changes its policy rule so that, at a given rate of inflation and output, it now sets a higher real interest rate than before. If it is assumed that the economy is initially at a long-run equilibrium position and there are no additional disturbances then, at the initial rate of inflation $\pi_{0}$ in figure 1 above, the MP line shifts up. As a result, the real interest rate rises and, consequently, the rate of output falls. However, unlike in the case shown above, output has fallen but the inflation rate has not changed. That is, the ADo curve has shifted to the left (to $\mathrm{AD}_{1}$ ) in figure 2 above so that, for an inflation rate like $\pi_{0}$, the real interest rate is now equivalent to $r\left(\pi_{1}\right)$ in the upper panel of figure 1.

The rate of output was initially determined at the intersection of the $\mathrm{AD} 0$ curve and the IA1 line at $\bar{Y}$ in figure 2. Since current output is now below $\bar{Y}$, the rate of inflation starts to fall and the IA 1 line begins to shift down. As a result, the economy moves down along the AD1 curve and output gets back towards its natural level. Again, the economy comes to rest at the point where the $\mathrm{AD}_{1}$ curve and the $\mathrm{IA}_{2}$ line intersect. In turn, the intersection corresponds to a rate of output $\bar{Y}$ and a lower (than the initial one) inflation rate $\pi_{1}$. In the new long-run equilibrium position, the real interest rate (and its corresponding MP line) is the same as before the change in the target inflation rate, i.e., the natural rate $r_{L R}$. Therefore, the change in the target inflation rate does not affect any real variables in the long run and. As Romer remarks, 'this analysis shows that monetary policy is a critical determinant of inflation in the long run' (Romer, 1999, p. 45). In addition to the determination of the rate of inflation, depending on the relative strength of the central bank response to the deviation of the rate of inflation and output 
from their respective targets - the natural rate of output being the target rate of output the central bank is in a position to determine the relative volatility of output and inflation. This is, for the proponents of the 'modern' view, the sole trade-off there is in monetary policy (Taylor, 1994, 1997; Solow and Taylor, 1998, pp. 31-33; Clarida et al., 1999, pp.1672-73).

\section{3.- Some problems}

In this section we discuss three controversial aspects of the IS-MP-IA model presented above. First, we address the formulation of the short-run inflation dynamics in the IS-MP-IA model. In the process, an alternative assumption for the determination of inflation dynamics is proposed. Second, we explore the consequences of dropping the assumption of the independence of aggregate demand and supply. Finally, we tackle the derivation of the aggregate demand curve.

\section{1.- Inflation dynamics}

As shown in section 2 above, the 'modern' view of the supply side of the economy can be summarized as follows: inflation at any point in time is given and, in the absence of inflation shocks, inflation rises when current output is above its natural rate and vice-versa. As a result, the short-run aggregate supply curve (referred to as the inflation adjustment line or IA) is horizontal in output-inflation space. Further, when current output is equal to potential output, the occurrence of unfavourable (favourable) inflation shocks shift the inflation adjustment line up (down). This view of the supply side of the economy strongly relies on the notion that a NAIRU (for non-accelerating 
inflation rate of unemployment) exists (Layard et al., 1991) so that, for rates of unemployment below the NAIRU, inflation rises and vice-versa.

Several considerations need to be made on this approach to modelling the supply side of the economy. First, there is considerable uncertainty surrounding the estimates of the NAIRU. For instance, Staiger et al. (1997) argue that estimates of the NAIRU (for the US economy) in 1994 range from 5.6 to 5.9, depending on the specification of the model. In addition, they stress that the estimates are imprecise since the shortest of the 95 percent confidence intervals for 1994 is of 4.8 to 6.6 percentage points. Taking account of uncertainty related to model selection increases sampling uncertainty even more. Likewise, in their study for the Canadian economy Setterfield et al. (1992) show that estimates of the NAIRU are very sensitive to model specification, the definition of variables, and the sample period used. For instance, the 67 models (encompassing different specifications, variables definitions and sample periods) which pass standard statistical tests produce estimated values of the NAIRU for prime age males ranging from $4.42 \%$ to $9.88 \%$, that is, almost 5.5 percentage points. Paradoxically, this range covers virtually the entire range of male unemployment rates in Canada since 1956. But even so, these coefficients have standard errors and, as a result, the range of NAIRU's produced by coefficients within one standard deviation of those in the above point estimates is from $4.18 \%$ to $10.33 \%$ (Setterfield et al., 1992, p. 133). According to Setterfield et al. (1992, p. 134), 'one clear implication of this is that whilst the selection of a particular NAIRU [see, for example, Bank of Canada (1988)] may impose enormous costs on an economy, both in the form of costs borne by unemployed individuals and in terms of forgone output, the NAIRU in use may depend to an unwarranted degree on how econometricians resolve technical issues of estimation'. 
The uncertainty surrounding the estimates of the NAIRU might not be a serious objection to its use for monetary policy purposes if it actually had the 'knife edge' properties that lead to rising (falling) inflation whenever current unemployment is below (above) its level. As Sawyer (2001, p. 226) points out, 'since the NAIRU is presented as a unique point (rather than, say, a plateau), this knife edge property appears to rule out even the smallest of deviations from the NAIRU'. Following Sawyer, according to the coefficients estimated by Layard et al. (1991) for the United States, 'for each 1 per cent unemployment is below the NAIRU, price inflation will rise by 1.4 per cent. Hence at the end of five years with unemployment 1 per cent point below $\mathrm{u}^{*}$ [NAIRU], inflation would be just over 7 per cent higher'. Similarly, Gordon (1997) postulates that 'unemployment 1 per cent lower than the NAIRU for starting at the end of 1997 through to 2005 would lead to inflation being 5.3 per cent higher in that year' (Sawyer, 2001, p. 226). As Galbraith (1997, p. 98) asserts, 'the fundamental implication of the natural rate hypothesis is that of tight limits on the rate of economic growth, lest inflation accelerate beyond control. However, the empirical evidence is in almost uniform agreement that inflation is highly inertial and that whatever limits may exist are at worst highly elastic'. All this empirical evidence suggests that a central bank that pursued an expansionary monetary policy to reduce unemployment would not run the risk of setting off an inflationary spiral and, in addition to this, if need be there would always be enough time to reverse policy.

Second, recent work on the short-run Phillips curve also indicates that the costs in terms of higher inflation of driving unemployment below the NAIRU may be rather low ${ }^{3}$. According to Eisner (1997), the US Phillips curve is concave. If this is indeed the case, the US Fed might drive unemployment below the NAIRU at a low cost in terms of inflation. According to Laxton et al. (1999, p. 1460), when serving as Chairman of the 
Council of Economic Advisers, Stiglitz urged the Fed to 'test the limits of capacity on the grounds that, owing to the absence of the 'traditional' convexity in the US case, the costs of error would be small'. Similarly, according to Eisner (1997, p. 198), 'while unemployment above the NAIRU may have lowered inflation in the United States, unemployment below the NAIRU has had little or no lasting effect in increasing inflation'. His results for the U.S. economy lend support for the original suggestion by Tobin (1955) that the Phillips curve is S-shaped. Finally, the empirical results obtained by Fair (1997a, 1997b, 2000) for a large set of countries also indicate that the estimated costs in terms of inflation of decreases in unemployment are worth incurring.

Lastly, closely linked to the modelling of the supply side by proponents of the 'modern' view is the assumption that high equilibrium unemployment is caused by rigidities and low search efficiency in the labour market. The latter has been a frequent diagnosis of high unemployment in some European countries. According to search theory, search efficiency and the reservation wage of the unemployed is affected by the income replacement ratio. For instance, 'if the unemployed are generously compensated by unemployment insurance, it can be assumed that they will search for jobs less energetically than they would have done if compensation had been more restricted' (Aberg, 2001, p. 132). After studying the case of Sweden - an example of generous welfare system - in the mid 1990s, Aberg (2001) finds a strong effect of unemployment duration on equilibrium unemployment. He also finds that getting a job is mainly associated with relative qualifications and labour market conditions rather than with search behaviour or wage demands. He suggests that long-term unemployment, especially when the rate of unemployment is high, can be best understood as a selection process - where job applicants' position in the queue of unemployed depends largely on their attractiveness to employers - rather than a search process. Importantly, the long- 
term unemployed appear to remain employable. These results suggest that the labour market is more likely to be demand-constrained rather than supply-constrained so that estimates of the equilibrium rate of unemployment tend to be too pessimistic about the potential for an expansionary macroeconomic policy.

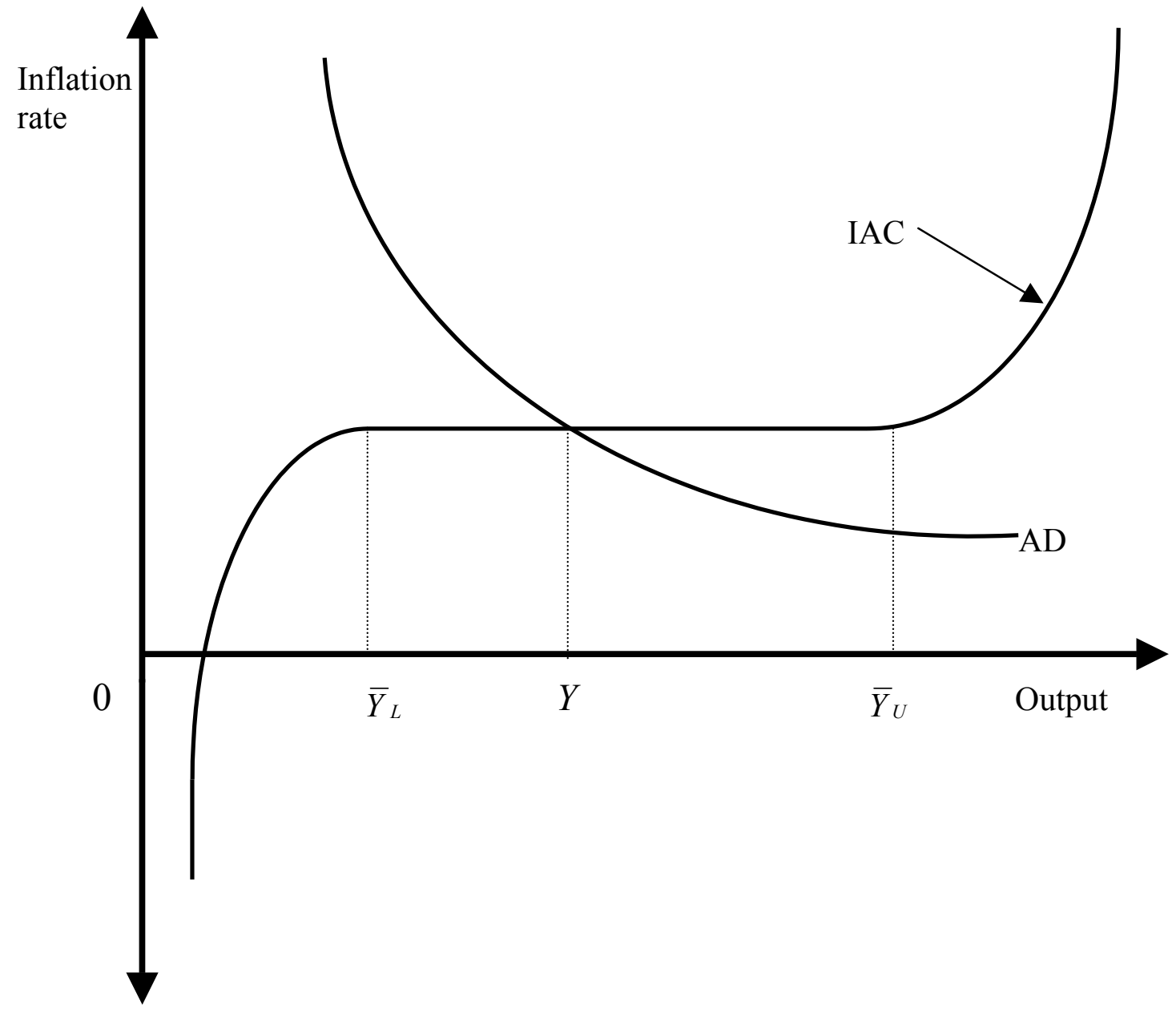

Figure 4: The inflation adjustment curve and the determination of the rate of output

What does all this evidence suggest?. We believe it suggests that the short-run output-inflation trade-off is better modelled in a different way of how it is done in the 'modern' view. Specifically, it suggests that the modelling of the supply side of the economy must allow for the possibility that the rate of inflation is roughly stable for a 
relatively wide range of rates of output and only increases or decreases when the current rate of output is outside this range. As can be seen in figure 4 above, for the range of output rates between the lower threshold $\bar{Y}_{L}$ and the upper threshold $\bar{Y}_{U}$ of the inflation adjustment curve (IAC), inflation remains constant in the absence of inflation shocks. Favourable inflation shocks shift the inflation adjustment curve (to be distinguished from the inflation adjustment line or IA) down and unfavourable inflation shocks shift it up. Finally, the current rate of output $Y$ is determined by the intersection of the IAC and AD curves.

Two final points should be noted. First, as can be seen in figure 4 above, there is some scope for an expansionary demand-management policy to increase output and thus reduce unemployment without fuelling inflation, at least in the short run. The long-run outcome of this policy as far as inflation is concerned is difficult to predict because it crucially depends on whether and to what extent a rising rate of aggregate demand leads to a rising rate of potential output in the long run. There are two approaches to this problem. On the one hand, there is the position advocated by the proponents of the 'modern' view, who prefer to consider the long-run level of output as independent of the level of aggregate demand (Solow, 1997; Solow and Taylor, 1998, pp. 31-3; Romer, 2000). For instance, Solow points out:

'The figures suggest that it would be awfully difficult for a surge of aggregate demand to generate enough investment to provide the capacity necessary to accommodate it $[\ldots]$ The demand-driven growth story sounds quite implausible to me under current conditions; but it is an example of the kind of question that needs to be asked' (Solow, 1997, pp. 232-3). 
On the other hand, there is the approach adopted by those authors who argue that demand-driven economic growth is plausible. Some recent theoretical (Rowthorn, 1999; Sawyer, 2002; Setterfield, 2002) and empirical (León-Ledesma and Thirlwall, 2002) work lends support for this claim. To it, we must add the more traditional arguments based on the notion of hysteresis or path-dependence equilibrium (Blanchard and Summers, 1987 and 1988; Cross, 1995; Ball, 1999) and the ubiquitous presence of static and dynamic increasing returns in the economy (Allyn Young, 1928; Kaldor, 1972). The consequences of assuming this latter scenario rather than the former are briefly explored below.

The second comment concerns the behaviour of central banks in the aftermath of adverse inflation shocks. As can be seen in figure 4, if an unfavourable inflation shock that raises current inflation above the inflation target leads to a tighter policy, i.e. a rise in the real interest rate, then as long as the rate of output remains above $\bar{Y}_{L}$ the rate of inflation will not fall despite the surge in unemployment. This suggests that an interest rate reaction function like the one proposed by Romer (2000) or any variant of the popular rule proposed by Taylor (1993) may be an inefficient way of coping with adverse inflation shocks in the scenario proposed here. Conversely, in the event of an adverse inflation shock it may well be preferable to keep 'real' interest rates constant and wait till a favourable inflation shock shifts the output-inflation trade-off down (Orphanides and Wilcox, 1996). On the other hand, in the event of a favourable inflation shock, a fall in the real interest rate and the subsequent rise in output will not trigger an inflationary spiral as long as the rate of output remains below $\bar{Y}_{U}$. Since, as suggested above, an expansionary policy is likely to expand capacity output, keeping real interest rates down may well set the economy into a virtuous circle of high output and low inflation. 


\section{2.- The independence of aggregate demand and aggregate supply}

Next, we address the crucial issue of the independence of aggregate demand and supply and its direct corollary, i.e. the long-run neutrality of monetary policy and money. The example of a reduction in the inflation target of the central bank considered in section 2 above will serve to briefly illustrate the possibility that monetary policy is non-neutral in the long run. If it is assumed that the economy is initially in a long-run equilibrium like $E_{L R O}$ in figure 5 below, and there are no additional disturbances then, at the initial inflation rate $\bar{\pi}_{0}$ a rise in the inflation target leads to a rise in the real interest rate. Then, as the aggregate demand curve shifts leftward - so that the new aggregate demand curve is $A D_{1}$ in figure 5 - the rate of output falls. The (lower) shortrun rate of output is determined by the intersection of the $I A_{0}$ line and the $A D_{1}$ curve. We now assume that the lower rate of aggregate demand reduces the physical capital stock per worker of the economy thereby reducing potential output ${ }^{4}$. As shown in Rowthorn (1999, p. 420), if the elasticity of substitution between capital and labour is less than one then variations in investment, the aggregate labour supply or technical progress $d o$ influence the equilibrium rate of unemployment. As a result, the vertical dotted line that indicates the initial rate of potential output $\bar{Y}_{0}$ shifts to the left so that the rate of potential output is now $\bar{Y}_{1}<\bar{Y}_{0}$. Since the current short-run rate of output is below $\bar{Y}_{1}$ then the rate of inflation eventually starts to fall and, as this occurs, the inflation adjustment line $I A_{0}$ shifts down. The new long-run equilibrium position $E_{L R 1}$ is reached at the rate of output $\bar{Y}_{1}$, i.e. at the intersection of the $A D_{1}$ curve and the $I A_{1}$ line. As can be seen in figure 5 below, in the new long-run equilibrium position $E_{L R 1}$ the real interest rate is higher, and both the rate of inflation and output are lower than in 
the initial position $E_{L R 0}$. Further, although inflation has fallen, it has not done so as much as it was the case when potential output was assumed to be independent of aggregate demand, i.e. the rate of inflation stays above $\bar{\pi}_{1}$ unless a further tightening of policy is implemented.

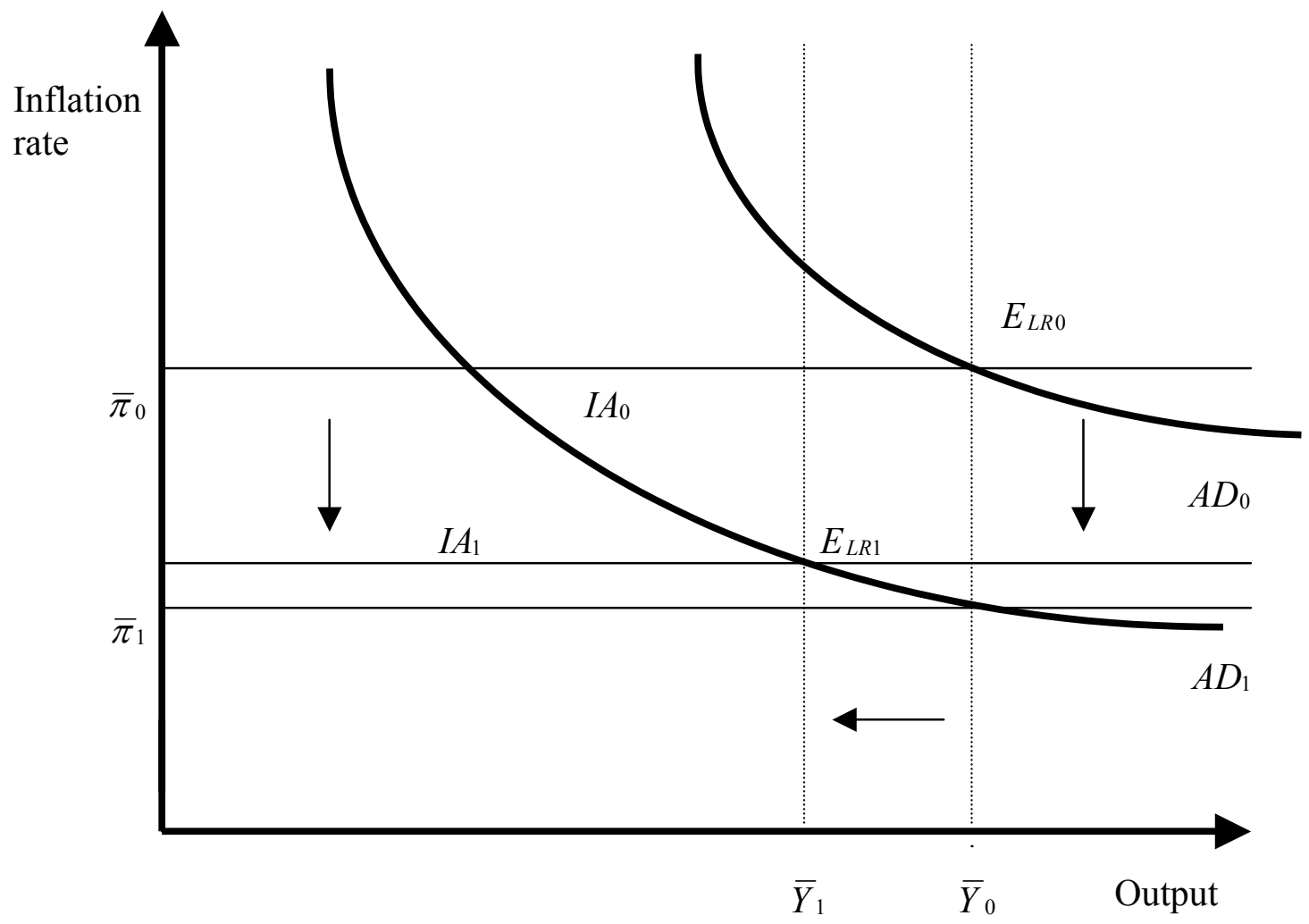

Figure 5: The case for long-run non-neutrality of monetary policy

The rise in the long-run equilibrium real interest rate highlights another result. When, in section 2 above, potential output was assumed to be independent of aggregate demand, the long-run equilibrium real interest rate $r_{L R}$ was constant regardless of the type and distribution of shocks hitting the economy and the monetary policy rule of the central bank. The long-run equilibrium real interest rate $r_{L R}$ could thus legitimately be referred to as the 'natural' real interest rate (Wicksell, 1936). However, when potential output is not independent of aggregate demand then, as shown above, the long-run 
equilibrium real interest rate $r_{L R}$ becomes a function of the type and probability distribution of supply, demand and inflation shocks, the monetary policy rule of the central bank and the - potentially changing - functional relationship between aggregate demand and aggregate supply. Needless to say, such a real interest rate now becomes a historical datum and it cannot legitimately be called 'natural'. Therefore, the above example shows that, if the assumption of the independence of aggregate demand and supply is dropped, then a change in the stance of policy does affect real variables in the long run.

\section{3.- The aggregate demand curve}

In section 2 we showed that the aggregate demand curve consists of an inverse relationship between the rate of inflation and output. It provides the rate of output relative to the natural rate of output - corresponding to every rate of inflation for a given real interest rate reaction function of the central bank. A first comment to make is that both the slope and position of the aggregate demand curve depend on the characteristics of the central bank interest rate reaction function. As for the position, it was shown in section 2 that it depends on the general stance of monetary policy. A tighter (looser) monetary policy, i.e., a fall (rise) in the inflation target, shifts the aggregate demand curve to the left (right). Of course, the position of the aggregate demand curve also depends on the rest of components of aggregate spending, including the budget deficit. As for the slope, as Taylor (1999a, p. 664) shows, a necessary condition for it to be downward sloping in output-inflation space is that, in the central bank reaction function, the nominal interest rate responds more than proportionately to a variation in the current rate of inflation so as to make the real interest rate an increasing function of the latter. 
As already said, this is also the requirement that any real interest rate rule must fulfil if it is to provide the economy with a nominal anchor. On this point, we wish to make two further considerations.

First, it is clear from this feature of the aggregate demand curve that there is no self-adjustment mechanism in the economy that ensures that it is downward sloping in output-inflation space. Therefore, we heavily rely on the competence, ability and vision of central bankers to adjust the nominal interest rate so as to make the ex-ante real interest rate an increasing function of the rate of inflation. If this requirement is not satisfied, then the aggregate demand curve will be horizontal or even upward sloping. Also related to this, it is clear from the literature on monetary policy rules that there have been historical episodes in which the behaviour of central banks did not fulfil this requirement (Judd and Rudebusch, 1998; Taylor, 1999b; Fair, 2001b) and when, as a result, the aggregate demand curve could not be said to have been downward sloping.

A second and more important consideration to make is connected to the fact that some proponents of the 'modern' view define the aggregate demand curve, not as an inverse relation between the rate of output and inflation but as an inverse relation between the output gap and inflation (Clarida et al., 1999, pp. 1665-66; Taylor, 2000). In its simplest form, the aggregate demand function is presented as $y=-a r+u$, where $y$ is the output gap, $r$ is the real interest rate and $u$ is a stochastic component with zero mean (see Taylor, 2000, p. 91). However, this relationship cannot hold unless it is assumed that aggregate demand shocks of the same sign and approximately similar magnitude shift the IS curve (and, therefore, the aggregate demand curve) to the right (left) whenever a favourable (unfavourable) supply shock raises (lowers) $\bar{Y}$. As argued below, such an assumption is profoundly un-Keynesian. The reason proposed by these 
authors to 'explain' how increases in potential output lead to equivalent increases in aggregate demand is as follows:

'Shocks to potential output also do not force a short-run trade-off. But they require a quite different policy response. Thus, e.g., a permanent rise in productivity raises potential output, but it also raises output demand in a perfectly offsetting manner, due to the impact of permanent income. As a consequence, the output gap does not change. In turn, there is no change in inflation. Thus, there is no reason to raise interest rates, despite the rise in output.' (Clarida et al., 1999, pp. 1675)

Apparently, these authors suggest that any increase in potential output is: (i) perfectly observed by individuals and (ii) interpreted as leading to an equivalent rise in income next period. In turn, insofar as individuals prefer to smooth consumption, expectation of higher income next period leads them to want to consume more today and tomorrow. As a result, through this mechanism, any variation in potential output is accompanied by a similar variation in aggregate demand. This is a restatement of Say's law. But Say's law only holds in a barter economy. In a monetary economy there is no guarantee at all that an increase in supply generates an amount of spending that absorbs the former. This is an essential insight of Keynesian macroeconomics, as several authors have long insisted (Davidson, 1972, 1978, 1984; Chick, 1983). Now, if there is no guarantee that an increase in potential output generates an equivalent increase in aggregate demand thereby leaving the output gap unchanged then, is there any other mechanism that helps fill the gap?. Let us see how Romer (1999) explains the effect of a favourable supply shock. Suppose the economy is initially at rest at a long-run equilibrium position corresponding to a rate of inflation $\pi_{1}$, a rate of output $\bar{Y}_{1}$ and a 
real interest rate $r\left(\pi_{1}\right)$ in figure 1 above. Assume, for instance that, as a result of an increase in labour productivity, the rate of potential output rises from $\bar{Y}_{1}$ to $\bar{Y}_{2}$. As Romer explains (1999, pp. 51-2), for an initial (current and potential) rate of output $\bar{Y}_{1}$, the increase in potential output from $\bar{Y}_{1}$ to $\bar{Y}_{2}$ will now make current output less than $\bar{Y}_{2}$. Thus, the rate of inflation will start to fall and the central bank will eventually lower the real interest rate. Graphically, as the rate of inflation falls, the $\mathrm{MP}_{1}$ line in figure 1 shifts down and aggregate demand rises along with it. The economy reaches a new long-run equilibrium position $E_{L R}$ at a higher rate of output $\bar{Y}_{2}$, a lower inflation rate $\pi_{2}$ and a lower real interest rate $r\left(\pi_{2}\right)$. This experiment can be easily extended to those cases in which factors like capital accumulation or increases in labour supply induce increases in potential output. Thus, in Romer's analysis of favourable supply shocks, the way an increase in potential output generates an equivalent increase in aggregate demand crucially depends on: (1) the fall in inflation as aggregate demand falls short of (higher) aggregate supply and (2) the ability of the central bank to - as inflation falls - lower the real interest rate so as to induce the appropriate increase in aggregate demand.

As for point (1), there is no guarantee that, starting from a long-run equilibrium position, a rise in potential output will lead to a fall in the rate of inflation. For this to occur, it must be assumed that inflation is predominantly demand-pull, i.e., that inflation rises when current output is above potential output and vice-versa. However, if either (1a) inflation is, as some authors have argued (Lavoie, 1996, p. 536), cost-push or (1b) the short-run output-inflation trade-off is - as suggested in section 3.1 above - roughly flat for a wide range of output values - then, there is no guarantee that an increase in potential output leads to a fall in inflation. This second scenario can be seen in figure 4 above. An increase in potential output will lead to a rightward shift of the inflation 
adjustment curve IAC. As long as the aggregate demand curve does not change and the intersection of the $\mathrm{AD}$ and IAC curves takes place within the flat range of the latter, both output and inflation will remain constant. Thus, there is no guarantee that condition (1) is satisfied.

As for condition (2), and in addition to the comments made above about the requirement any policy rule must fulfil in order to guarantee that the aggregate demand curve is downward sloping, several considerations need to be made. First, in the context of the neoclassical synthesis, increases in potential output lead overtime to an equivalent increase in aggregate demand - thereby avoiding the possibility of the emergence of a 'general glut on the market' - if the wealth effect that arises from the falling price level is stronger than the substitution effect caused by an expected rate of decline of prices. The operation of the wealth effect is as follows. The increase in aggregate supply leads, for an initial level of aggregate demand, to a fall in the price level. Insofar as the central bank is assumed to keep nominal money supply (or its rate of growth in a dynamic setting) constant, the fall in the price level leads to a rise in real money balances which, in turn, increases aggregate spending both directly, as the rise in real money balances expands the real financial wealth of households and translates, in turn, into an increased demand for commodities, and indirectly, as the falling price level and the rising real money balances reduces the supply of bonds by firms and increase the demand for bonds by households respectively thereby leading to a fall in the real interest rate and, consequently, to a rise in the demand for investment goods. As for the operation of the substitution effect, an expected rate of decline of prices makes both money and bonds preferable to commodities and, therefore, it tends to reduce aggregate demand (Patinkin, 1965, pp. 359-65). As a result, in the context of the neoclassical synthesis, the classical position is rationalized 'by assuming that the aggregate demand for commodities is 
sufficiently sensitive to the stimulating effects of the interest and price changes generated by the expanding supply so as to increase at the same pace as the latter' (Patinkin, 1965, p. 360).

Three comments suffice, according to us, to downplay this story as an account of how economic growth may occur within a 'modern' view of macroeconomics ${ }^{5}$. First, there is the notion that, excluding government bonds in the hands of the private sector, the net financial wealth of the private sector is roughly equal to the monetary base (Kalecki, 1944). Since the latter represents a very small proportion of the money stock in modern market economies, the deflation that would be required to generate an adequate increase in aggregate demand would simply be catastrophic (see Tobin, 1993, pp. 59-60 and Sawyer, 2001, pp. 240-41). To this, we must add the scepticism about the relevance of the real-balance effect expressed by its proponents (Pigou, 1943; Patinkin, 1948, pp. 271-77, 1965, pp. 364). Second, there is the additional problem that the aggregate demand curve may not, after all, be downward sloping in output-price space ${ }^{6}$ (Patinkin, 1965, pp. 335-40). Rather, it is more likely to be vertical (see Fazzari et al., 1998, pp. 548-53). Third, and foremost, if the central bank sets the interest rate, then money supply is endogenous ${ }^{7}$ (Clarida et al., 1999, p. 1667; Orphanides and Wieland, 2000, p. 1359; Taylor, 1999b, p. 661; Svensson, 1999, p. 611) and, as a result, the realbalance effect in non-existent. As Moore argues:

'Firms require short-term finance for all increases in their working capital needs over their production-sales period. As a result [...] changes in the supply of credit money are positively related to changes in the money wage rate and the level of employment. Observed changes in money wage rates, prices, output, and the supply of credit money are in consequence all highly intercorrelated and collinear [...] In a credit 
money economy there is no Pigou effect, so that the aggregate demand curve is vertical in output-price space' (Moore, 1988, p. 327).

In short, a falling price level is to be followed by a falling nominal money stock so that the real value of the money stock will remain roughly constant. Consequently, the real-balance effect is either negligible or, crucially, non-existent. Translated to our discussion above this means that, although the proponents of the neoclassical synthesis could rely - insofar as the central bank was assumed to target money supply - on the assumption of relatively strong effects on the aggregate demand for commodities of the interest and price changes generated by an expanding supply, proponents of the 'modern' view cannot resort to this mechanism.

A second and final consideration to make is that, to be fair, it seems that when telling the above story about the adjustment of aggregate demand to a favourable supply shock, Romer may not actually insinuate this is the way economic growth is brought about. Notwithstanding this possibility, we believe that if the IS-MP-IA framework can account for the effects of favourable supply shocks, it should also be able to provide a coherent story of how growth comes about. However, from our discussion above, it can be seen that this is not the case. Let us see why. In the example of an increase in potential output shown above, both the rate of inflation $\pi_{2}$ and the real interest rate $r\left(\pi_{2}\right)$ are lower in the new long-run equilibrium position (see figure 1 above). In the absence of positive demand shocks of sufficient magnitude, as potential output keeps rising then further cuts in the real interest rate will be required to generate additional increases in aggregate demand. However, there is a limit to the possibility by central banks to continuously engineer increases in aggregate demand through cuts in real interest rates. One crucial limitation arises because what the central bank sets is a short- 
term nominal interest rate. But nominal rates have a zero lower bound. Once the nominal interest rate has reached this lower bound no additional cuts are possible. Furthermore, this problem is independent of the monetary policy rule implemented by the central bank. Thus, as Tobin points out:

'The Keynesian insight is that the institutionally fixed nominal interest rate on currency, generally, zero, limits the adjustment of nominal interest rates on non-money assets and imparts to them some stickiness even when they are above zero. As a result, after an aggregate demand shock they may not fall automatically to levels low enough to induce sufficient investment to absorb full employment saving [...] The interest rate on money sets the floor for other nominal market interest rates' (Tobin, 1993, p. 53).

In addition, if the economy enters a deflationary spiral at the time when the nominal interest rate is close to zero, the real interest rate will rise - rather than fall thereby aggravating the deflationary process. Further, since central banks only set shortterm nominal interest rates and the relevant rates for spending decisions are long-term real rates, then as Tobin (1993, p. 54) argues, 'because traditional expectations of future long rates persist in slumps, current long rates do not automatically follow short rates down far enough to induce the spurts in investment needed for recovery'. Finally, to these problems, we must add the traditional doubts about the efficacy of interest rate cuts to stimulate investment demand in a context of pervasive uncertainty (Shackle, 1946) and the absence of a reliable empirical relationship between real interest rates and investment (Stiglitz, 1988, p. 310). When all these arguments are put together, it is clear that the prospects for central banks to generate a level of aggregate demand that matches a rising level of potential output through the management of interest rates are uncertain. 


\section{4.- An alternative framework}

Finally, we address the determination of the short-run rate of inflation and output once all the above comments and considerations are incorporated into the analysis. As shown in figure 6 below, the rate of inflation $\pi_{0}$ and output $Y$ are determined by the intersection of the AD and IAC curves.

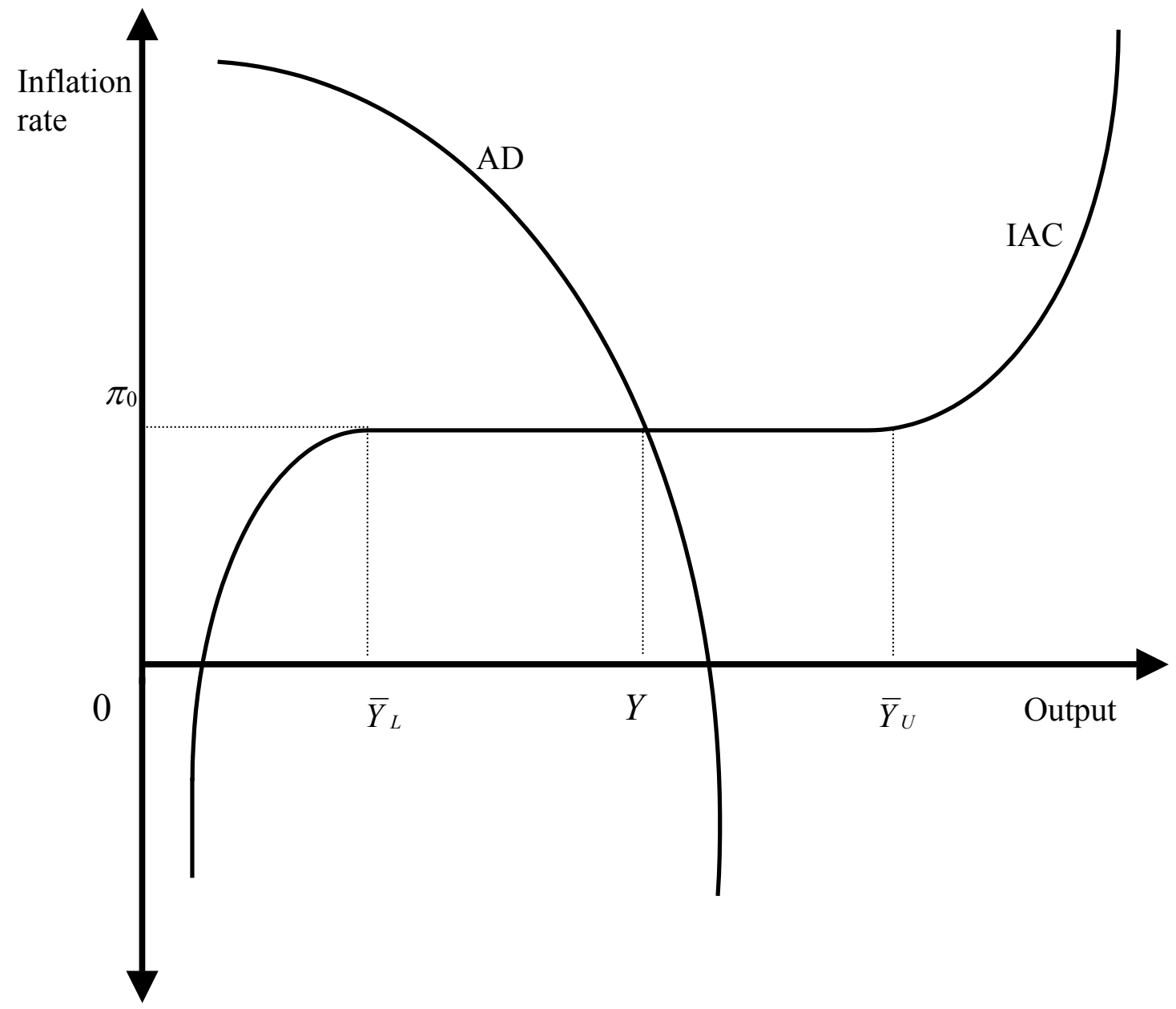

Figure 6: The determination of the rate of inflation and output in the short run

The specific shape of the AD curve is due to the fact that (provided the interest rate reaction function of the central bank has the desirable properties): (i) as inflation 
goes up it becomes easier for central banks to lower real interest rates and thus stimulate aggregate demand whereas, conversely, as inflation approaches zero, it is increasingly difficult for central banks to do so as a result of the existence of a zero lower bound on nominal interest rates and (ii) as inflation rises, the central bank is willing to forego a higher rate of output in order to prevent the rate of inflation from rising further. It could be added that as inflation falls, the central bank will attempt to expand output although, as argued in (i) above, it will be increasingly difficult to do so. Since their ability to stimulate aggregate spending through the management of interest rates is confined to the downward sloping segment of the AD curve then, as figure 6 above shows, aggregate demand becomes the crucial exogenous variable in the short run (Keynes, 1936, Ch. 3; 1937, p. 221). However, as our discussion on the dependence of aggregate demand and supply suggests, it may also play an important role in the long run because, a stronger aggregate demand may rise, in turn, capacity output. Therefore, the extent to which the supply side of the economy sets a limit to the expansion of aggregate demand overtime depends on (i) the relative size of the flat segment of the IAC curve, (ii) the pace at which the latter shifts rightward relative to the rate of growth of aggregate demand and (iii) the distribution of inflation shocks that hit the economy. Finally, figure 6 also indicates that, at least for low rates of inflation, the probability distribution of the rate of inflation and output will reflect the probability distribution of inflation and demand shocks respectively, as shown in Orphanides et al. (1997).

\section{5.- Conclusion}

In an attempt to adapt the IS-LM model to the new realities, Romer $(1999,2000)$ and Taylor (2000) have proposed an alternative framework, i.e., the IS-MP-IA model. 
An advantage of the new model is that, along with recent policy developments, it assumes that central banks target the real interest rate through an interest rate policy reaction function. Proponents of the new framework claim that it represents de facto a 'modern' view of macroeconomics (Taylor, 2000, p. 90). Conversely, in this paper we argued that, although the new framework may actually become a 'modern' view of macroeconomics, it nevertheless remains closely attached to the neoclassical synthesis insofar as Keynesian results are obtained in the short run but Classical results prevail in the long run. We also argued that, despite some advances in terms of realism, the new framework fails to take account of: (i) the recent empirical evidence on the nature of the short-run output-inflation trade-off, (ii) the recent theoretical and empirical work on the interdependence of aggregate demand and supply, (iii) the limitations monetary policy is subject to and (iv) the consequences for demand-management policy of considering (i), (ii) and (ii). In particular, when these theoretical elements are incorporated onto the analysis, we have that short-run stabilization policy is non-neutral in the long run, loanable funds theory becomes irrelevant and aggregate demand turns into the crucial exogenous variable in the short run and, perhaps, also in the long run.

\section{References}

Aberg, R. (2001): "Equilibrium unemployment, search behaviour and unemployment persistency", Cambridge Journal of Economics, 25(2), pp. 131-47.

Allsopp, C. and D. Vines (2000); “The Assessment: Macroeconomic Policy", Oxford Review of Economic Policy, 16(4), pp. 1-32.

Allyn Young (1928); “Increasing Returns and Economic Progress”, Economic Journal, 38(152), December, pp. 527-42. 
Ball, L. (1999): “Aggregate Demand and Long-Run Unemployment”, Brookings Papers on Economic Activity, 2, pp. 189-236.

Bank of England (1999); "The transmission mechanism of monetary policy", Bank of England Quarterly Bulletin, 39 (2), May, pp.1-12.

Bernanke, B.S. and F.S. Mishkin (1997); “Inflation Targeting: A New Framework for Monetary Policy?”, Journal of Economic Perspectives, 11(2), Spring, pp. 97-116.

Bernanke, B.S., T. Laubach, F.S. Mishkin and A.S. Posen (1999); Inflation Targeting: Lessons from the International Experience, Princeton: Princeton University Press.

Blanchard, O.J. and L. H. Summers (1987): "Hysteresis in Unemployment”, European Economic Review, 31, pp. 288-295.

Blanchard, O.J. and L.H. Summers (1988); "Beyond the Natural Rate Hypothesis", American Economic Review, Papers and Proceedings, 78(2), May, pp. 182-87.

Blinder, A. (1988); “The Fall and Rise of Keynesian Economics”, Economic Record, 64(187), December, pp. 278-94.

Clarida, R., J. Galí, and M. Gertler (1999); "The science of monetary policy: a New Keynesian perspective", Journal of Economic Literature, 37 (4), pp. 1661-707.

Chick, V. (1983); Macroeconomics After Keynes, Cambridge (MA): The MIT Press.

Cross, R. (ed.) (1995); The Natural Rate of Unemployment, Cambridge, UK: Cambridge University Press.

Davidson, P. (1972); Money and the Real World, London: Macmillan.

Davidson, P. (1978); "Why money matters: lessons from a half-century of monetary theory", Journal of Post Keynesian Economics, 1(1), pp. 46-70. 
Davidson, P. (1984); “Reviving Keynes's Revolution”, Journal of Post Keynesian Economics, 6(4), Summer, pp. 561-75.

De Long, J.B. (1999); “Should We Fear Deflation?”, Brookings Papers on Economic Activity, 1, pp. 225-52.

Eisner, R. (1997); “A new view of the NAIRU”, in P. Davidson and J. A. Kregel (eds.) Improving the Global Economy. Keynesianism and the Growth in Output and Employment, Cheltenham (UK): Edward Elgar.

European Central Bank (2001); The Monetary Policy of the ECB, Internet document, http: \www.ecb.de/pub/pdf/monetarypolicy2001.pdf.

Fair, R.C. (1997a); “Testing the NAIRU Model for 27 Countries”, Cowles Foundation, April.

Fair, R.C. (1997b); "Estimated inflation costs had European unemployment been reduced in the 1980s by macro policies", Cowles Foundation, December.

Fair, R.C. (2000); "Testing the NAIRU model for the United States", Review of Economics and Statistics, 82(1), pp. 64-71.

Fair, R.C. (2001a); 'Is there empirical support for the 'modern' view of macroeconomics?", Cowles Foundation Discussion Paper, No.1300, April.

Fair, R.C. (2001b); “Actual Federal Reserve Policy Behavior and Interest Rate Rules”, Federal Reserve Bank of New York Economic Policy Review, 7(1), pp. 61-72.

Fazzari, S.M., P. Ferri and E. Greenberg (1998); "Aggregate demand and firm behavior: a new perspective on Keynesian microfoundations", Journal of Post Keynesian Economics, 20(4), pp. 495-526. 
Fontana, G. and Palacio-Vera, A. (2002); "Monetary policy rules: what are we learning?", Journal of Post Keynesian Economics, 24(4), pp. 547-568.

Galbraith, J. (1997); "Time to Ditch the NAIRU”, Journal of Economic Perspectives, 11(1), pp. 93-108.

Goodfriend, M. (1991); "Interest rates and the conduct of monetary policy", CarnegieRochester Conference Series on Public Policy, 34 (1), pp. 7-30.

Gordon, R. (1997); “The Time-Varying NAIRU and its Implications for Economic Policy", Journal of Economic Perspectives, 11(1), Winter, pp. 11-32.

Judd, J.P. and G.D. Rudebusch (1998); “Taylor's Rule and the Fed: 1970-1997”, Federal Reserve Bank of San Francisco Economic Review, 3(361), pp. 3-16.

Kaldor, N. (1972); “The Irrelevance of Equilibrium Economics”, Economic Journal, 82(328), December, pp. 1237-55.

Kalecki, M. (1944); "Professor Pigou on the 'Classical Stationary State' - A Comment", Economic Journal, Vol. 54, April, pp. 131-32.

Keynes, J.M. (1936); The General Theory of Employment, Interest and Money, London: Macmillan.

Keynes, J.M. (1937); “The General Theory of Employment”, Quarterly Journal of Economics, February, pp. 209-23.

Laxton, D, D. Rose and D. Tambakis (1999): “The U.S. Phillips curve: The case for asymmetry", Journal of Economic Dynamics and Control, 23, pp. 1459-85.

Layard, R., S. Nickell, and R. Jackman (1991); Unemployment: Macroeconomic Performance and the Labour Market, Oxford: Oxford University Press. 
Lavoie, M. (1996); "Monetary Policy in an Economy with Endogenous Credit Money”, in G. Deleplace and E.J. Nell (eds.), Money in Motion: The Post Keynesian and Circulation Approaches, pp. 532-545, London: Macmillan.

León-Ledesma, M.A. and A.P. Thirlwall (2002); “The endogeneity of the natural rate of growth", Cambridge Journal of Economics, 26, July, pp. 441-59.

Moore, B.J. (1988); Horizontalists and Verticalists: The Macroeconomics of Credit Money. New York: Cambridge University Press.

Orphanides, A. and D.W.Wilcox (1996); “The Opportunistic Approach to Disinflation”, Board of Governors of the Federal Reserve System, May.

Orphanides, A., D.H. Small, V. Wieland and D.W. Wilcox (1997); “A Quantitative Exploration of the Opportunistic Approach to Disinflation”, Board of Governors of the Federal Reserve System, June.

Orphanides, A. and V. Wieland (2000); "Inflation zone targeting", European Economic Review, 44, pp. 1351-87.

Palley, T.I. (2002); "Endogenous money: what it is and why it matters", Metroeconomica, 53(2), pp. 152-80.

Patinkin, D. (1948); "Price flexibility and full employment", American Economic Review, 38, pp. 543-64. Reprinted in F.A. Lutz and L.W. Mints (eds.) Readings in Monetary Theory, Ch.13, pp. 252-83, London: George Allen and Unwin Ltd.

Patinkin, D. (1965); Money, Interest, and Prices, 2nd edition, New York: Harper and Row.

Pigou, A.C. (1943); “The Classical Stationary State”, Economic Journal, Vol. 53, December, pp. 343-51. 
Romer, D. (1999); “Short-Run Fluctuations”, Working Paper, August, University of California, Berkeley.

Romer, D. (2000); "Keynesian Macroeconomics without the LM Curve”, Journal of Economics Perspectives, 14(2), Spring, pp. 149-69.

Rowthorn, R. (1999); "Unemployment, wage bargaining and capital-labour substitution", Cambridge Journal of Economics, 23(4), pp. 413-26.

Sawyer, M.C. (2001); “The NAIRU: a critical appraisal”, in P. Arestis and M.C. Sawyer (eds.) Money, Finance and Capitalist Development, pp. 220-54, Cheltenham, UK: Edward Elgar.

Sawyer, M.C. (2002); “The NAIRU, Aggregate Demand and Investment", Metroeconomica, 53(1), pp. 66-94.

Setterfield, M.A., D.V. Gordon and L. Osberg (1992): "Searching for a Will o' the Wisp: An empirical study of the NAIRU in Canada", European Economic Review, 36, pp. 119-36.

Setterfield, M. (ed.) (2002); The Economics of Demand-led Growth, Cheltenham, UK: Edward Elgar.

Shackle, G.L.S. (1946); “Interest Rates and the Pace of Investment”, Economic Journal, 56 (221), March, pp. 1-17.

Solow, R.M. (1997); "Is There a Core of Usable Macroeconomics We Should All Believe In?", American Economic Review, Papers and Proceedings, May, pp. 230-32.

Solow, R.M. and J.B. Taylor (1998); Inflation, Unemployment, and Monetary Policy, Cambridge, MA: The MIT Press.

Staiger, D., J.H. Stock, and M.W. Watson (1997); “The NAIRU, Unemployment and Monetary Policy", Journal of Economic Perspectives, 11(1), Winter, pp. 33-49. 
Stiglitz, J.E. (1988); "Money, Credit, and Business Fluctuations", Economic Record, 64 (187), December, pp. 307-22.

Svensson, L.E.O. (1999); "Inflation targeting as a monetary policy rule", Journal of Monetary Economics, 43, pp. 607-54.

Taylor, J.B. (1993); “Discretion Versus Policy Rules in Practice”, Carnegie-Rochester Conference Series on Public Policy, 39, pp. 195-214.

Taylor, J.B. (1994): "The Inflation/Output Variability Trade-off Revisited", in J.G. Fuhrer (ed.) Goals, Guidelines, and Constraints Facing Monetary Policymakers, Federal Reserve Bank of Boston, Conference Series No.38, pp. 21-38.

Taylor, J.B. (1997); “A Core of Practical Macroeconomics”, American Economic Review, Papers and Proceedings, 87(2), May, pp. 233-35.

Taylor, J.B. (1999a); “The Robustness and Efficiency of Monetary Policy Rules as Guidelines for Interest Rate Setting by the European Central Bank", Journal of Monetary Economics, 43(3), pp. 655-79.

Taylor, J.B. (1999b); "A historical analysis of monetary policy rules" in J.B. Taylor (ed.) Monetary Policy Rules, pp. 319-41, Chicago: University of Chicago Press.

Taylor, J.B. (2000); “Teaching Modern Macroeconomics at the Principles Level", American Economic Review, Papers and Proceedings, 90(2), May, pp. 90-94.

Tobin, J. (1955); “A Dynamic Aggregative Model”, Journal of Political Economy, Vol. 63, April, pp. 103-15.

Tobin, J. (1975); "Keynesian Models of Recession and Depression”, American Economic Review, Papers and Proceedings, 65(2), May, pp. 195-202.

Tobin, J. (1993); "Price Flexibility and Output Stability: An Old Keynesian View", Journal of Economic Perspectives, 7(1), Winter, pp. 45-65. 
Wicksell, K. (1936; 1965); Interest and Prices, translated by R.F. Kahn, New York:

Augustus M. Kelly.

${ }^{1}$ See Stiglitz (1988, pp. 312-17) and Bank of England (1999) for a description of the transmission mechanism of monetary policy through interest rates.

${ }^{2}$ However, Fair (2001a) finds that data support the use of nominal rather than real interest rates in aggregate expenditure equations.

${ }^{3}$ See also Blinder (1988, p. 283) for a supportive position on the validity for the US, even in the long run, of Phillips curves that are negatively sloped in unemployment-inflation space when due account is taken of adverse supply shocks.

${ }^{4}$ It should be noted that, as the above discussion on the slope of the short-run output-inflation trade-off highlighted, it may take a long time before a tightening of monetary policy reduces inflation. As long as this is the case, higher real interest rates might, in the meantime, adversely affect capacity output. In general, the flatter the output-inflation trade-off curve is, the longer it takes for inflation to fall and, as a result, the more likely it is that a contractionary monetary policy will negatively affect the productive capacity of the economy.

${ }^{5}$ Although the first two comments below are applicable to the neoclassical synthesis story told above as well.

${ }^{6}$ Patinkin (1965, pp. 335-40) discusses some of the reasons why a falling price level may not have a stimulating effect on aggregate demand. For instance, he refers to the distributive effects that increase and reduce the relative income of creditors and debtors respectively thereby adversely affecting aggregate demand. Similarly, he suggests the possible postponement of spending as a result of expectations of further declines in prices. A discussion of the dangers that deflation poses for the economy with an empirical application for the US economy can be found in De Long (1999) and a complete analytical treatment of the ability of a deflationary process to restore full employment can be found in Tobin (1975). Finally, it might be argued that the aggregate demand curve is downward sloping for an open economy insofar as a falling price level increases international competitiveness. However, this stimulating effect on aggregate demand has to be weighted against the negative effects mentioned above.

${ }^{7}$ We believe that, unlike to what mainstream authors imply, money supply is endogenous regardless of the monetary policy regime implemented by the central bank. As shown in Fontana and Palacio-Vera (2002), this is the position adopted by the proponents of the endogenous money hypothesis, for whom the endogeneity of money is a logical necessity of the economy rather than a consequence of the monetary policy regime adopted by a particular central bank. See Palley (2002) for a discussion of the different meanings of money endogeneity in economic theory. 